\title{
Role of Microbes in Phosphorus Availability and Acquisition by Plants
}

\author{
Amarjeet Kumar ${ }^{1 *}$, Ajeet Kumar ${ }^{1}$ and Himanshu Patel ${ }^{2}$ \\ ${ }^{1}$ Department of Soil Science and Agricultural Chemistry, Bihar Agricultural University, \\ Sabour, Bhagalpur, Bihar (813 210), India \\ ${ }^{2}$ Department of Soil Science and Agricultural Chemistry, Indira Gandhi Krishi \\ Vishwavidyalaya, Krishak Nagar, Raipur, Chhattisgarh, India \\ *Corresponding author
}

\begin{tabular}{|l|}
\hline Ke y w o r d s \\
Soil phosphorus, \\
Phosphate solubilizing \\
microbes, Organic acid, \\
Inorganic acid, \\
Acquisition
\end{tabular}

\section{A B S T R A C T}

Phosphorus (P) is limiting for crop yield on $>30 \%$ of the world's arable land and, by some estimates, world resources of inexpensive phosphorus may be depleted by 2050 (Vance $e t$ al., 2003). It is the second important key plant nutrient after nitrogen. An adequate supply of phosphorus is therefore required for proper functioning and various metabolisms of plants. Majority of phosphorus in soils is fixed and hence, plant available phosphorus is scarcely available despite the abundance of both inorganic and organic phosphorus forms in soils. A group of soil microorganism's play significant role in transforming insoluble P into soluble and plant accessible forms across different genera, have been found as best eco-friendly option for availability of phosphorus in soils (Khan et al., 2014). Phosphorous solubilisation is carried out by a large number of saprophytic bacteria and fungi acting on sparingly soluble soil phosphates, mainly solubilized by the action of organic and inorganic acids secreted by phosphate solubilizing microorganisms in which hydroxyl and carboxyl groups of acids chelate cations ( $\mathrm{Ca}, \mathrm{Al}$ and $\mathrm{Fe}$ ) and decrease the $\mathrm{pH}$ in basic soils (Yadav and Varma, 2012). The phosphate solubilizing microorganisms also dissolved the phosphorus through production acids such as (acetate, lactate, oxalate, tartarate, succinate, citrate, gluconate, keto-gluconate and glycolate (Elizabeth et al., 2017). Babu V. S. (2016) found that the application of Bacillus and Pseudomonas species increase the phosphate solubilisation efficiency 258.33 and 161.60 percent respectively. The complexity of phosphorus nutrition of plants arises because the availability and uptake of phosphorus depends on the interaction between soil, plant, and microbial processes. Phosphorus acquisition in low phosphorus conditions, plants change root growth and development by promoting the formation of a shallow, highly branched root system through a reduction of primary root growth, and an increase in adventitious roots and lateral root density, as well as the development of more and longer root hairs (Bovill et al., 2013).

\section{Introduction}

Phosphorus is an essential nutrient for all living, and nonliving organisms. It is a vital element for plant and animal nutrition and the second-most limiting nutrient after nitrogen for plant growth and crop production in many agricultural areas. It is a critical global resource, alongside water and energy resources. It is one of the essential elements 
required for plant growth and reproduction. It is often referred to as an energy source, helps in storage and turnover of energy during photosynthesis. Phosphorus is also found in certain storage compounds in seeds of plants. Phosphorus is a vital component of deoxyribonucleic acid (DNA), the genetic "memory unit" of all living things (Marshner, 1995). Some specific growth factors that have been associated with phosphorus are stimulated root growth, increased stalk and stem strength, improved flower formation and seed production, more uniform and earlier crop maturity, increased N-fixing capacity of legumes, improvements in crop quality, and increased resistance to plant diseases. Availability of phosphorus on the production and productivity of crop is also required to study for sustainable agriculture. In the earth crust Common minerals present in acid soils are Strengite $\left(\mathrm{FePO}_{4} .2 \mathrm{H}_{2} \mathrm{O}\right)$, Variscite $\left(\mathrm{AlPO}_{4} \cdot 2 \mathrm{H}_{2} \mathrm{O}\right)$. Neutral and calcareous soils tricalcium phosphate $\left[\mathrm{Ca}_{3}\left(\mathrm{PO}_{4}\right)_{2}\right]$, Dicalcium phosphate $\left(\mathrm{CaHPO}_{4}\right)$, Dicalcium phosphate dihydrate $\left(\mathrm{CaHPO}_{4} \cdot 2 \mathrm{H}_{2} \mathrm{O}\right), \quad$ Fluorapatite $\left[\mathrm{Ca}_{5}\left(\mathrm{PO}_{4}\right)_{3} \mathrm{~F}\right]$, Hydroxyapatite $\left[\mathrm{Ca}_{5}\left(\mathrm{PO}_{4}\right)_{3}\right.$ $\mathrm{OH}]$ and Octacalcium phosphate $\left[\mathrm{Ca}_{4} \mathrm{H}\left(\mathrm{PO}_{4}\right)_{3} \cdot 2-5 \quad \mathrm{H}_{2} \mathrm{O}\right] . \quad$ Organicaly phosphorus bound containing compound Phytin (a $\mathrm{Ca}-\mathrm{Mg}$ salt of phytic acid) is the most abundant of the known organophosphorus compounds in soils. Other organic $\mathrm{P}$ in soils occur as sugar phosphates, nucleotides $(0.2-2.5 \%)$, phosphoprotein (trace), phosphonates (Tate, 1984) and phospholipids (1-5 \%) (Yadav and Verma 2012). Of the various forms of phosphorus, plants take up only negatively charged primary and secondary orthophosphate ions $\left(\mathrm{H}_{2} \mathrm{PO}_{4}{ }^{-1}\right.$ and $\left.\mathrm{HPO}_{4}{ }^{-2}\right)$ as nutrient. The phosphorus cycle is the biogeochemical cycle that describes the movement of phosphorus through the lithosphere, hydrosphere, and biosphere many other biogeochemical cycles, the atmosphere does not play a significant role in the movement of phosphorus, because phosphorus and phosphorus-based compounds are usually solids at the typical ranges of temperature and pressure found on Earth. Phosphates move quickly through plants and animals; however, the processes that move them through the soil or ocean are very slow, making the phosphorus cycle overall one of the slowest biogeochemical cycles. Initially, phosphate weathers from rocks and minerals, the most common mineral being apatite. Overall small losses occur in terrestrial environments by leaching and erosion, through the action of rain. In soil, phosphate is adsorbed on iron oxides, aluminium hydroxides, clay surfaces, and organic matter particles, and becomes incorporated (immobilized or fixed). Plants and fungi can also be active in making Phosphorus soluble.

\section{Mineralization of phosphorus}

Mineralization is the microbial conversion of organic phosphorus to $\mathrm{H}_{2} \mathrm{PO}_{4}{ }^{-1}$ or $\mathrm{HPO}_{4}{ }^{-2}$, forms of plant available $\mathrm{P}$ known as orthophosphates or the mineralization process results in increased bioavailability of the phosphorus that were contained in the organic compounds being decomposed, especially (because of their quantities) phosphorus. Whether the decomposition of an organic phosphorus will result in mineralization or immobilization is dependent on its concentration relative to that of carbon. Use of organic $\mathrm{P}$ by plants and microorganisms requires mineralization (hydrolysis) of substrates by phosphatase enzymes that may be of either plant or microbial origin. Increased activity of phosphatases occurs in response to phosphorus deficiency as part of phosphorus starvation responses. In plants, this includes the release from roots of extracellular phosphatases that are considered to be important for capture and recycling of organic phosphorus lost from roots, or to allow greater access to soil organic 
phosphorus (Richardson et al., 2005). Increased mineralization of soil organic matter associated with higher microbial activity also occurs in the rhizosphere as a result of a microbial priming effect due to utilization of exudate carbon with subsequent mineralization of nutrients from soil organic matter (Cheng, 2009). However, the direct coupling of carbon mineralization with amounts of $\mathrm{N}$ (and $\mathrm{P}$ ) released requires more detailed investigation. While $\mathrm{C}$ : $\mathrm{N}$ ratios are reasonably constant across different soils and for various fractions of soil organic matter, wider variation in $\mathrm{C}$ : $\mathrm{P}$ or $\mathrm{C}$ : organic $\mathrm{P}$ ratios are often observed (Kirkby et al., 2011).

\section{Phosphorus solubilization}

Phosphate solubilization beneficial microbes capable of solubilizing inorganic phosphorus from insoluble compounds. P-solubilization ability of rhizosphere microorganisms is considered to be one of the most important traits associated with plant phosphate nutrition. Using microbes to improve solubilization of lowly available forms of soil Phosphorus. Number of soil microbes have been identified to solubilize insoluble Phosphorus complexes into solution making it possible for its uptake by plants. Several species of fungi and bacteria, commonly known as phosphate-solubilizing microorganisms (PSMs) help the plants in mobilizing insoluble forms of phosphate. PSMs improve the solubilization of phosphates fixed in soil resulting in their uptake by plants and higher crop yields. Significant increase in grain yield was reported for rice, chickpea, lentil, soybean and cowpea when Pseudomonas striata, Aspergillus awamori and Bacillus polymyxa were used either singly or in combination. Several bacteria, fungi including mycorrhizal fungi and actinomycetes are highly capable of converting insoluble phosphate into soluble inorganic phosphate ion. Adhya et al., (2015) reported that the several microbes are like Bacteria Bacillus megaterium, B. circulans, $B$. subtilis, $B$. polymyxa, $B$. sircalmous, Pseudomonas striata, Enterobacter species, Beggiatoa and Thiomargarita, Actinobacteria like Sacchromonospora viridis, Actinomodura citrea, Micromonospora echinospora, Saccharopolyspora hirsute, Streptomyces albus, Streptoverticillium album, Streptomyces cyaneus and Thermonospora mesophila, Fungi Belonging to genera Aspergillus (A. awamori) and Penicillium ( $P$. bilaii) and Mycorrhiza Belonging to genera Glomus, Rhizophagus, Sclerocystis, Claroideoglomus, Gigaspora, Scutellospora, Entrophospora, Pacispora, Diversispora, Otospora, Paraglomus, Geosiphon, Ambispora, Archaeospora spp. etc.

Phosphorus solubilization is carried out by a large number of bacteria and fungi acting on sparingly soluble soil phosphates, mainly by chelation-mediated mechanisms (Whitelaw 2000). Inorganic Phosphorus is solubilized by the action of organic and inorganic acids secreted by PSB in which hydroxyl and carboxyl groups of acids chelate cations $(\mathrm{Al}, \mathrm{Fe}$, and $\mathrm{Ca}$ ) and decrease the $\mathrm{pH}$ in basic soils (Kpomblekou and Tabatabai, 1994; Stevenson 2005; Jha et al., 2013). The PSB dissolve the soil Phosphorus through production of low molecular weight organic acids mainly gluconic and keto gluconic acids (Goldstein 1995; Deubel et al., 2000), in addition to lowering the $\mathrm{pH}$ of rhizosphere. The $\mathrm{pH}$ of rhizosphere is lowered by proton/bicarbonate release (anion/cation balance) and gaseous $\left(\mathrm{O}_{2} / \mathrm{CO}_{2}\right)$ exchanges. Release of root exudates such as organic ligands can also alter the concentration of $\mathrm{P}$ in soil solution (Hinsinger, 2001). Solubilization of phosphorus by biochemical mechanism of phosphorus releases the 2-keto gluconic acid produced from direct oxidation of glucose by phosphate solubilizing bacteria play an important role in weathering and solubilization of phosphates in soil. Very efficient solubilization of rock phosphate by Erwinia herbicola and Pseudomonas cepacia is the result of gluconic ( $\mathrm{pKa} \sim 3.4)$ and 2-keto gluconic acids (pKa 2.4) formed by direct oxidation of glucose. Some bacteria undertake the direct oxidation pathway to such elevated levels that externally added glucose is quantitatively converted to gluconic acid at concentration of $1 \mathrm{~mol} \mathrm{l}^{-1}$ or higher. Gramnegative bacteria are more efficient at 
dissolving mineral phosphates when compared to gram-positive bacteria because of the release of several organic acids into the extracellular medium. Thermo tolerant acetic acid producing Acetobacter and Gluconobacter also have the direct oxidation pathway with thermotolerant glucose dehydrogenase (GDH) and solubilize mineral phosphate. Several other organic acids such as acetic, lactic, malic, succinic, tartaric, oxalic and citric acids are also produced. Weak organic acids, viz. malate, acetate and succinate are present in the rhizosphere as fermentation products of rhizobacteria. Pseudomonas sp. is known to preferentially utilize these weak organic acids over glucose, sucrose and fructose. Similar catabolite repression of glucose metabolism is found in root nodule bacteria. Many pseudomonads are also known to solubilize mineral phosphates by secretion of gluconic acid.

The insoluble forms of $\mathrm{P}$ such as tricalcium phosphate $\left(\mathrm{Ca}_{3} \mathrm{PO}_{4}\right)_{2}$, aluminium phosphate $\left(\mathrm{Al}_{3} \mathrm{PO}_{4}\right)$, iron phosphate $\left(\mathrm{Fe}_{3} \mathrm{PO}_{4}\right)$, etc. may be converted to soluble phosphorus by phosphorus solubilizing microbes inhabiting different soil ecosystems (Gupta et al., 2007; Song et al., 2008; Khan et al., 2013; Sharma et al., 2013). Soil microorganisms in this regard have generally been found more effective in making $\mathrm{P}$ available to plants from both inorganic and organic sources by solubilizing (Toro, 2007; Wani et al., 2007a) and mineralizing complex $\mathrm{P}$ compounds (Bishop et al., 1994; Ponmurugan and Gopi, 2006), respectively.

\section{References}

Babu V. S. (2016). Evaluation of efficiency and persistence of different phosphate solubilizing biofertilizers with maize crop. Int.J.Curr.Microbiol.App.Sci. 6(10): 2090-2101.
Bovill, W. D., Huang, C. Y. and Donald, G. K. M. (2013). Genetic approaches to enhancing phosphorus-use efficiency (PUE) in crops: challenges and directions Crop and Pasture Science, 64(3): 179198.

Cheng W. X. (2009). Rhizosphere priming effect: its functional relationships with microbial turnover, evapotranspiration, and C-N budgets. Soil Biol Biochem., 41: 1795-1801.

Elizabeth, T. A., Bernard, R. G. and Olubukola, O. B. (2017). Microbial Phosphorus Solubilization and Its Potential for Use in Sustainable Agriculture. Front Microbiology, 8: 971.

Khan, Md. S., Zaidi, A. and Ahmad E. (2014). Mechanism of Phosphate Solubilization and Physiological Functions of Phosphate-Solubilizing Microorganisms. Phosphate Solubilizing Microorganisms, 2: 31-52.

Tate K. R. (1984). The biological transformation of $\mathrm{P}$ in soil. Plant Soil 76:245-256

Vance, C.P., Stone, C U. and Allan, D. L. (2003). Phosphorus acquisition and use: critical adaptations by plants for securing a non-renewable resource. New Phytologist, 157: 423-447.

Yadav, B. K. and Varma, A. (2012). Phosphate solubilization and mobilization in soil through microorganisms under arid ecosystems. The Functioning of Ecosystems Prof. Mahamane Ali (Ed.), InTech, Available from: http://www.intechopen. com/books/thefunctioning-ofeco-systems/phosphatesolubilization-and-mobilization-in-soilthrough-micro-organisms-under-aridecosystems.

\section{How to cite this article:}

Amarjeet Kumar, Ajeet Kumar and Himanshu Patel. 2018. Role of Microbes in Phosphorus Availability and Acquisition by Plants. Int.J.Curr.Microbiol.App.Sci. 7(05): 1344-1347. doi: https://doi.org/10.20546/ijcmas.2018.705.161 